\title{
Comparison between ELISA and PCR for Detection of Epstein-Barr Virus in Head and Neck Malignancies
}

\author{
Shahid Rasool ${ }^{1}$, Rafiq A Pampori ${ }^{2}$, Sabhiya Majid ${ }^{3}$, Hilal Wani ${ }^{4}$, Rabiya Farooq ${ }^{5}$, Suhail Patigaroo ${ }^{6}$
}

\begin{abstract}
This is a comparative prospective study conducted for a period of 2 years from December 2012 to December 2014 in the Postgraduate Department of Otorhinolaryngology, Head and Neck Surgery, Government Medical College, Srinagar, in collaboration with the Department of Biochemistry. A total of 118 subjects were enrolled in the study design, which included 98 histopathologically confirmed head and neck malignant cases and 20 healthy controls. The aim of the study was to compare the ELISA with polymerase chain reaction (PCR) for detection of Epstein-Barr virus (EBV) in head and neck carcinoma cases and compare such results with controls.

Results: Around 32.65 and $42.85 \%$ of patients were positive for EBV with PCR and ELISA, respectively. When these results were compared with controls, it showed statistically significant results; only $5 \%$ of subjects in controls were positive for EBV ( $p$ value $=0.015$ ) with PCR while as many as $15 \%$ with ELISA ( $p$ value $=0.049$ ). The sensitivity and specificity of ELISA are 100 and $84.85 \%$, respectively, with diagnostic accuracy of the test $89.8 \%$ (Cohens $\kappa$ value $=0.7853$ ).

Keywords: ELISA for Epstein-Barr virus, Epstein-Barr virus, Head and neck carcinomas, Laryngeal carcinomas, Oral tumors, PCR for Epstein-Barr virus. International Journal of Head and Neck Surgery (2020): 10.5005/jp-journals-10001-1389
\end{abstract}

\section{INTRODUCTION}

Head and neck carcinomas are a heterogeneous group of malignancies and can be classified into different subgroups according to the primary tumor site and the histological type. Squamous cell carcinoma (SCC) is the most common histology in mucosal sites of the upper aerodigestive tract. Nasopharyngeal carcinoma (NPC), with a unique geographical and ethnic distribution and high radio- and chemosensitivity, is usually considered separately from other head and neck carcinomas. The undifferentiated subtype of NPC has a strong association with Epstein-Barr virus (EBV). ${ }^{1-3}$ Head and neck squamous cell carcinoma (HNSCC) is thought to account for an estimated 650,000 new cancer cases and 350,000 cancer deaths worldwide per year. ${ }^{4}$ Alcohol consumption and smoking tobacco have been implicated in approximately $75 \%$ of HNSCC. 5 Chewing tobacco or betel quid are known risk factors for HNSCC. ${ }^{7}$ EBV is a herpesvirus that has been linked to several human malignancies. ${ }^{8}$ It is present in the tumor tissue of nasopharyngeal undifferentiated carcinoma and various lymphoid malignancies. ${ }^{1-3,8,9}$ The virus is also present in the tumor cells of a number of nonnasopharyngeal head and neck carcinomas (NNHNCs). ${ }^{10-19}$ In particular, it is strongly associated with lymphoepithelial carcinoma (LECA) of the salivary glands in Eskimos and Asian patients. ${ }^{1,16,17,20,21}$ The antigens of EBV are either the nuclear core early antigen (EA) or the viral capsid antigen (VCA). EBVassociated malignancies are often characterized by markedly high titers against EA and IgG/lgA VCA. The EBV genome is contained in all malignant NPC cells and it encodes viral proteins that contribute to the malignant phenotype. ${ }^{22,23}$ Epstein-Barr virus positivity (EBVP) in lymphoma is discerned in $70 \%$ of mixed cellularity, $95 \%$ of lymphocyte-depleted lymphoma cells, and $10-40 \%$ of nodular sclerosis; the lymphocyte-predominant Hodgkin's disease subtype is almost always EBV negative. ${ }^{24}$ Several types of non-B-cell, nonHodgkin's lymphoma are associated with EBV. ${ }^{25,26}$

\footnotetext{
${ }^{1}$ Department of ENT, Hamdard Institute of Medical Sciences and Research, New Delhi, India

${ }^{2}$ Department of Otorhinolaryngology and Head and Neck Surgery, Government Medical College, Srinagar, Jammu and Kashmir, India

${ }^{3-5}$ Department of Biochemistry, Government Medical College, Srinagar, Jammu and Kashmir, India

${ }^{6}$ Department of ENT, Government Medical College, Srinagar, Jammu
} and Kashmir, India

Corresponding Author: Shahid Rasool, Department of ENT, Hamdard Institute of Medical Sciences and Research, New Delhi, India, Phone: +91 9650177009, e-mail: srb948@gmail.com

How to cite this article: Rasool S, Pampori RA, Majid S, et al. Comparison between ELISA and PCR for Detection of Epstein-Barr Virus in Head and Neck Malignancies. Int J Head Neck Surg 2020;11(1):6-11.

Source of support: Nil

Conflict of interest: None

\section{Materials and Methods}

The present study was conducted in the Postgraduate Department of Otorhinolaryngology, Head and Neck Surgery, Government Medical College, Srinagar, in collaboration with the Department of Biochemistry. Presently, comparative noninvasive plasma-/serumbased detection of cell-free EBV DNA by polymerase chain reaction (PCR)-based methods is being done. In this study, we compared ELISA with PCR in detection of EBV from plasma samples of all cases and controls. All patients of histopathologically confirmed malignancies of head and neck were enrolled in the study after a proper written consent. Thyroid cancers, metastatic carcinomas from other sites, and carcinoma with unknown primary were excluded from the study. All enrolled patients were evaluated in

() The Author(s). 2020 Open Access This article is distributed under the terms of the Creative Commons Attribution 4.0 International License (https://creativecommons. org/licenses/by-nc/4.0/), which permits unrestricted use, distribution, and non-commercial reproduction in any medium, provided you give appropriate credit to the original author(s) and the source, provide a link to the Creative Commons license, and indicate if changes were made. The Creative Commons Public Domain Dedication waiver (http://creativecommons.org/publicdomain/zero/1.0/) applies to the data made available in this article, unless otherwise stated. 
detail, and full ENT workup was done. Beside routine investigations, special investigations like CECT, MRI, USG, fiber-optic laryngoscopy, and sinonasal endoscopy were performed as and when required for proper staging and comprehensive management.

A 5-mL venous blood sample was collected from each cases and controls in heparin vials and sent to the Department of Biochemistry where serum was separated using a centrifuge and the remaining blood was stored at $-20^{\circ} \mathrm{C}$ for future use. Freshly separated serum samples were used for detection of the antibody of IgM class against the EBV capsid antigen in all cases and controls using ELISA (DS-EIA-ANTI-EBV-VCA-M kit). DNA was extracted from stored blood samples by using the DNA extraction kit (Zymo Research USA). Extracted DNA was stored at $-20^{\circ} \mathrm{C}$ for future analysis.

\section{Real-time PCR}

Polymerase chain reaction amplification was done on a thermal cycler (Eppendorf) using the Norgen PCR kit (Norgen Biotech Corp, Canada). Polymerase chain reaction products after amplification were run on $2 \%$ agarose gel to detect amplicons. These amplicons were visualized by the gel documentation system (GENETIX).

\section{Results}

Out of total 98 patients, 70 were males and 28 females with male/ female ratio of 2.5:1.The lowest age encountered was 2 years while the oldest being of 75 years with the mean age of 48.54 and median of 57.5 years. A total of $7(14.28 \%)$ patients were from urban areas while $42(85.71 \%)$ were from rural areas. A total of 68 (69.38\%) patients were active smokers while only 30 (30.61\%) were nonsmokers. None of the patients were alcoholic or tobacco chewer. The most common tumor encountered in the study was carcinoma of larynx with 40 cases $(40.81 \%)$, followed by lymphomas with 20 cases $(20.40 \%)$, and the least common was carcinoma of external ear, with only 2 cases. Table 1 shows the site distribution of tumors.

It was seen that 42 patients out of 98 were positive for the $\operatorname{lgM}$ EBV antibody by ELISA (42.85\%). Highest number of patients positive for EBV IgM antibodies with ELISA were of NPC (75\%), followed by salivary gland tumors (66.66\%) and lymphomas (60\%). Same is depicted in Table 2 and Figure 1.

It was seen that the EBV DNA detected by PCR was present in $32.65 \%$ of nonendocrine head and neck malignancies only. Highest percentage of EBV DNA is seen in patients of NPC (75\%) followed by lymphomas (40\%), as shown in Table 3.

It was seen that with increase in the tumor " $\mathrm{T}$ " and/or the nodal " $\mathrm{N}$ " stage of the tumor, the percentage of EBVP increased by the ELISA method. For TI/T2, EBVP was 20\% and increased to $50 \%$ when the stage was T3/T4 with the $p$ value of 0.043 (Fischer's exact test), which is statistically significant. While for the $\mathrm{N}$ stage, EBVP was $27.77 \%$ in N0 and increased to $50 \%$ in the N1/N2 stage,

Table 1: Site distribution of head and neck tumors

\begin{tabular}{lcc}
\hline Site & No. of cases & Percentage \\
\hline Ca larynx & 40 & 40.81 \\
Lymphomas & 20 & 20.40 \\
Sinonasal & 16 & 16.32 \\
Oral cavity & 10 & 10.20 \\
Salivary glands & 6 & 6.12 \\
Hypopharyngeal & 4 & 4.08 \\
EAC carcinoma & 2 & 2.04 \\
Total & 98 & 100 \\
\hline
\end{tabular}

\begin{tabular}{lcll}
\multicolumn{2}{l}{ Table 2: ELISA (EBV) vs site of tumor } \\
\hline Site of malignancy & No. of patients & ELISA (+ve) & Percentage \\
\hline Laryngeal & 40 & 18 & 45 \\
Lymphomas & 20 & 12 & 60 \\
NPC & 8 & 6 & 75 \\
Sinonasal & 8 & 2 & 25 \\
Oral cavity & 10 & $\mathrm{Nil}$ & 00 \\
Salivary gland & 6 & 2 & 66.66 \\
Hypopharyngeal & 4 & $\mathrm{Nil}$ & 00 \\
EAC & 2 & $\mathrm{Nil}$ & 00 \\
Total & 98 & 42 & 42.85 \\
\hline
\end{tabular}

with the $p$ value of 0.198 (Fischer exact test), which is insignificant as shown in Table 4

It was seen that with increase in the " $\mathrm{T}$ " and /or " $\mathrm{N}$ " stage of the tumor, the percentage of EBVP increased by the PCR method also. For $\mathrm{T} 1 / \mathrm{T} 2$, the EBVP was $25 \%$ and increased to $35 \%$ in T3 and $50 \%$ in T4, respectively, with $p$ value of 0.504 (Fischer exact test). For N0/ $\mathrm{N} 1$, EBVP was $\sim 27 \%$ and increased to 38.46 in N2 with the $p$ value of 0.734 (Fischer exact test), which is statistically insignificant. Table 5 depicts the same.

Table 6 and Figure 2 show that the plasma EBV is seen in $42.85 \%$ of patients as against only $15 \%$ in the control group, with $p$ value of 0.049 (Fischer exact test), which is statistically significant.

From Tables 7, 8 and Figure 3, it is seen that the plasma EBV detection by PCR in patients is $32.65 \%$ as compared to only $5 \%$ in controls with $p$ value of 0.015 (Fischer exact test), which is statically significant.

\section{Discussion}

In the study, males were more commonly affected than females. Out of 98 patients in our study, 70 were males and 28 were females with the M/F ratio of 2.5:1. We believe that male predilection is because of them being addicted to smoking, alcoholism, and tobacco chewing and being fortunate enough to be brought to tertiary center for treatment. Many other studies have found this male predilection in head and neck malignancies like the study by Yu et al., ${ }^{27}$ Atlana et al. ${ }^{28}$ and Abdulamir et al. ${ }^{29}$

We found that most of our patients (70\%) presented to us in the fourth decade of life. A study by Kamel et al. ${ }^{30}$ has also found maximum number of $\mathrm{HN}$ malignancy in this decade, while the National Cancer Institute ${ }^{31}$ observed that head and neck cancers are diagnosed more often among people over age 50 than they are among young people. Early presentation of patients in our study may be because of the fact that in Kashmir heavy smoking by young population is on rise due to heavy psychological trauma and may be also because of easy access to the tertiary care hospital (GMC, Srinagar).

The present study has $70 \%$ of patients who were smokers while only $30 \%$ were nonsmokers, which is consistent with the study of Wyss et al., ${ }^{32}$ who in his study found that cigarette smokers had elevated odds ratios for head and neck cancers, and extensive literature about the smoking and head and neck carcinomas confirmed our observations.

The most common carcinoma in our study was carcinoma of larynx followed by lymphomas; carcinoma of larynx was found in $40(40 / 98)$ patients ( $40.81 \%)$, which was similar to the study of Majid et al. ${ }^{33}$ who in his study found that 20 out of 41 head and neck carcinomas were laryngeal carcinomas (48.78\%). Similar findings were seen in the study of Yu et al., ${ }^{27}$ who in his study "Plasma 


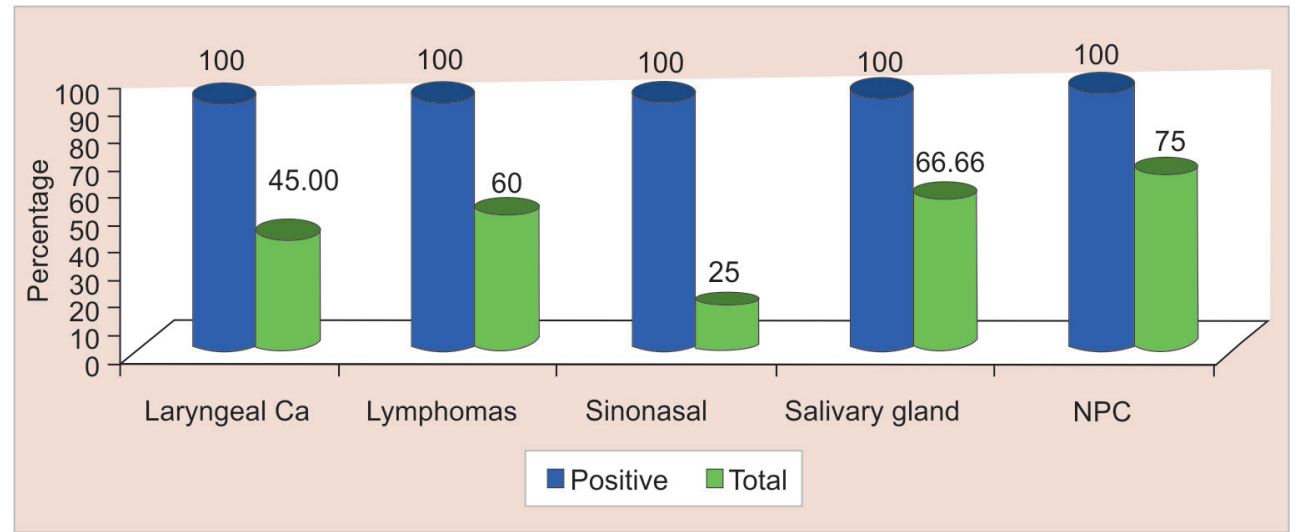

Fig. 1: Percentage of head and neck tumors positive for EBV with ELISA method

Table 3: PCR (EBV DNA) results in relation to site of tumor

\begin{tabular}{lccc}
\hline Site of malignancy & No. of patients & PCR positive & Percentage \\
\hline Laryngeal & 40 & 14 & 35 \\
Lymphomas & 20 & 8 & 40 \\
NPC & 8 & 6 & 75 \\
Sinonasal & 8 & 2 & 25 \\
Oral cavity & 10 & $\mathrm{Nil}$ & 0 \\
Salivary glands & 6 & 2 & 33.33 \\
Hypopharyngeal & 4 & $\mathrm{Nil}$ & 0 \\
EAC & 2 & $\mathrm{Nil}$ & 0 \\
Total & 98 & 32 & 32.65 \\
\hline
\end{tabular}

Table 4: Tumor node metastasis (TNM) staging vs ELISA (EBV) $(n=76)$, HNSCC and LEC

\begin{tabular}{lllll}
\hline Staging & & No. of patients & ELISA (+ve) & Percentage \\
\hline T stage & T1 & 10 & 2 & 20 \\
& T2 & 22 & 4 & 18.18 \\
& T3 & 40 & 22 & 55 \\
\multirow{5}{*}{ N stage } & T4 & 4 & 2 & 50 \\
& N0 & 36 & 10 & 27.77 \\
& N1 & 14 & 8 & 57.14 \\
& N2 & 26 & 12 & 46.15 \\
M stage & N3 & 0 & 0 & 0.00 \\
& M0 & 76 & 30 & 39.47 \\
& M & 0 & 0 & 0.00 \\
\hline
\end{tabular}

Table 5: TNM staging and PCR (EBV) $(n=76)$

\begin{tabular}{lccc}
\hline Staging & No of patients & $P C R(+v e)$ & Percentage \\
\hline T stage & & & \\
T1 & 10 & 0 & 0.00 \\
T2 & 22 & 8 & 36.36 \\
T3 & 40 & 14 & 35 \\
T4 & 4 & 2 & 50 \\
N stage & & & \\
N0 & 36 & 10 & 27.77 \\
N1 & 14 & 4 & 28.57 \\
N2 & 26 & 10 & 38.46 \\
N3 & 0 & 0 & 0.00 \\
M stage & & & \\
M0 & 76 & 24 & 31.57 \\
M & 0 & 0 & 0.00 \\
\hline
\end{tabular}

Table 6: Comparison of EBV detection by ELISA between patients and controls

\begin{tabular}{llll}
\hline Samples & Total no. of patients & ELISA & Percentage \\
\hline Patients & 98 & 42 & 42.85 \\
Controls & 20 & 3 & 15.00 \\
\hline
\end{tabular}

EBV DNA in Head and Neck Carcinomas" encountered 40 (39.6\%) patients with carcinoma of larynx out of 101 of total cases.

Heavy smoking especially by young population in recent years due to psychological trauma by political disturbance has probably lead to rise in number of laryngeal carcinoma patients as observed in our study.

Epstein-Barr virus PCR positivity in laryngeal carcinoma patients in our study was 35\% (14 out of 40), which was similar to the study done by Muderris et al. ${ }^{34}$ entitled "Does Epstein-Barr Virus Infection Have an Influence on the Development of Laryngeal Carcinoma? Detection of EBV by Real-Time Polymerase Chain Reaction in Tumour Tissues of Patients with Laryngeal Carcinoma"; they found EBV PCR positivity in $40 \%(10 / 25)$ of the laryngeal carcinoma patients.

Similar observations were confirmed by Yu et al. ${ }^{27}$ who found that plasma EBV DNA is detectable in $20.0 \%$ of the patients.

Oral cavity was seen to be involved in only 10 (10.20\%) of our cases. The reason for this low percentage is that gutka and tobacco chewing is not common in Kashmiri population. None of the patients were positive for EBV with either ELISA or PCR. This is in disagreement with Mao and Smith ${ }^{35}$ and Horiuchi et al. ${ }^{36}$ who showed that $35 \%$ and $33.3 \%$ of their examined SCC of oral cavity cases, respectively, were infected with EBV. They stated that the positive rate was higher in malignant lesions than in benign ones and agreed that EBV had a role in carcinogenesis. The similar disagreement with our study was also seen in the study of Sand et al. ${ }^{37}$ on the "prevalence of Epstein-Barr virus in oral squamous cell carcinoma (OSCC), oral lichen planus (OLP), and normal oral mucosa (NOM)." They examined 29 patients of OSCC, 23 OLP, and 67 NOM cases for EBV DNA analysis. They found that prevalence of EBV in patients with oral mucosal disease is $32.1 \%$. Of the OSCC patients $37.9 \%$ and of the OLP $26.1 \%$ were positive for EBV.

The current study found only eight (8.16\%) cases of NPCs and this low percentage seen in our study is well documented in the literature. In spite of being less in number, NPC was the most common tumor associated with EBV, with six out of eight (75\%) cases being positive for the virus. The results were same with both ELISA (EBV anti-IgM VCA) and PCR. Similar findings of high viral 


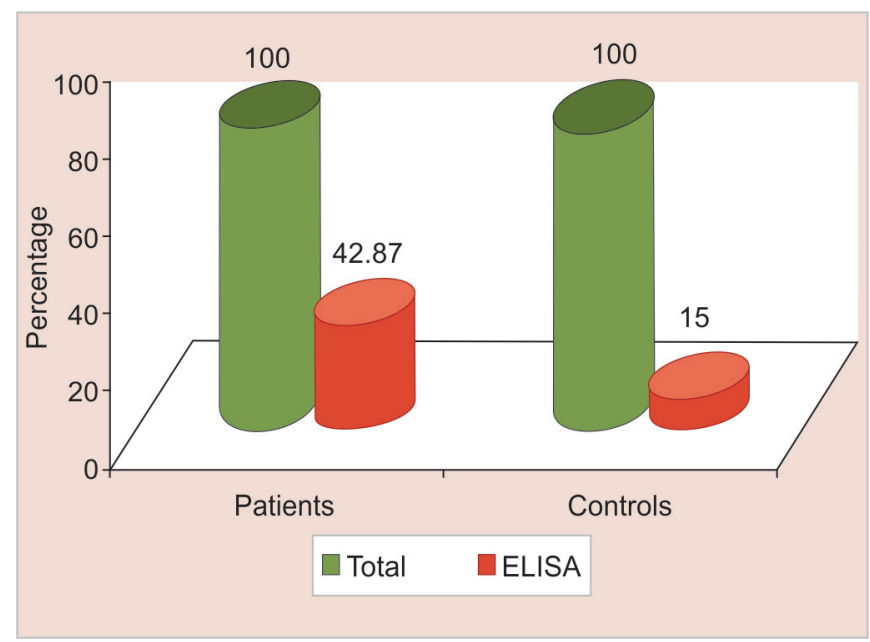

Fig. 2: Positive EBV ELISA in $42.85 \%$ of patients compared to $15 \%$ in the control group, with $p$ value of 0.049 (Fischer exact test), which is statistically significant

Table 7: Comparison of EBV detection by PCR between patients and controls

\begin{tabular}{llcc}
\hline & $\begin{array}{l}\text { Total no. of } \\
\text { patients }\end{array}$ & $P C R$ & Percentage \\
\hline Patients & 98 & 32 & 32.65 \\
Controls & 20 & 1 & 5.00 \\
\hline
\end{tabular}

Note: It is seen that ELISA is positive in $42.85 \%$ of patients while $P C R$ is positive in only $32.65 \%$ with sensitivity of $100 \%$ and specificity of $84.85 \%$. Diagnostic accuracy of the test is $89.8 \%$. Cohens $\kappa$ value $=0.7853$

Table 8: Sensitivity and specificity of ELISA with respect to PCR

\begin{tabular}{llll}
\hline Tests & Total & Positive & Percentage \\
\hline ELISA & 98 & 42 & 42.85 \\
PCR & 98 & 32 & 32.65 \\
\hline
\end{tabular}

positivity have been noted by Tiwawech et al. ${ }^{38}$ who in their study found that serum IgA/EBNA1 levels were positive in $52(96.30 \%)$ out of 54 NPC patients and in 5 (4.10\%) out of 122 healthy controls. Twu et al. ${ }^{39}$ studied 116 NPC patients and stated that 106 of 114 NPC (92.98\%) patients had detectable plasma EBV DNA by RTQ-PCR before treatment, whereas no detectable EBV DNA was found in 63 SCCHN patients and 50 healthy people.

In the present study, hypopharyngeal cancer was seen in only four (4.08\%) patients and none was positive for EBV with either the ELISA or PCR method. In contrast, study by Yu et al. ${ }^{27}$ shows EBV detection rate to be $43.8 \%$ in 16 patients of hypopharynx cancer.

The current study had 20 (20.40\%) cases of lymphomas, which included 6 Hodgkin's and 16 non-Hodgkin's lymphomas with the EBVP of $40 \%$ with PCR. Reports less than our observations were seen by Trimeche et al. ${ }^{40}$ who in his study found that 28 out of 126 cases (22.2\%) of lymphomas were positive for EBV by in situ hybridization.

In the present study, ELISA was found positive for IgM anti-VCA (EBV) in $42.85 \%$ (42/98) of patients in contrast to only $15 \%(3 / 20)$ of controls, which is statistically significant $(p=0.049)$, while in HNSCC it was found in $30.55 \%$ patients only (22/72), which is in contrast with the results of Morshed et al. ${ }^{41}$ who in his study indicated that only 5 (12.8\%) of 38 patients with HNSCC were positive for anti-VCA (IgM) and all the controls showed negative results. Similar contrast results were also noted by Kim et al. $^{42}$ who in his study found 9 (12\%) of the total 72 patients of HNC showed EBVP of tumor, which

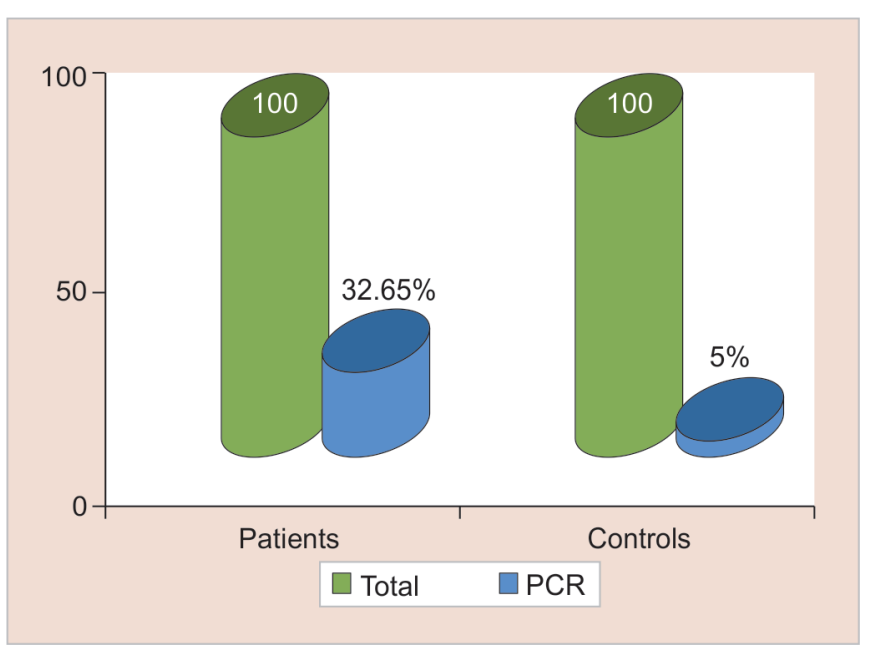

Fig. 3: $32.65 \%$ of patients \& $5 \%$ of controls have EBV positive with PCR, $p$ value of 0.015 (Fischer exact test), which is statistically significant

depends mainly on pathology and sites but not on tumor staging, age, sex, or smoking status. While a study by Majid et al. ${ }^{33}$ found that the serum antibody levels against VCA $(\lg A)$ and EA $(\lg A)$ were significantly elevated in patients with SCC when compared to controls, which is consistent with our results.

The current study showed that $32.65 \%$ (22/98) of patients and $5 \%(1 / 20)$ of controls had EBVP when PCR was employed as the detection method, with the $p$ value of 0.035 , which is statistically significant (Fischer exact test). Similar reports were confirmed by Yu et al. ${ }^{27}$ who in his study observed that 30 patients $(29.7 \%)$ and 2 controls (4.2\%) had detectable plasma EBV DNA. The difference in proportion was statistically significant $(p=0.0004)$. Plasma EBV DNA was detected in all of the patients with Epstein-Barr virus encoded RNA-positive tumors and in 23 of 94 (24.5\%) patients with tumors of EBER-negative or unknown status. The proportion of plasma EBV DNA-positive cases in either group was significantly higher than that in the controls ( $p=0.0027)$, which is in accordance with our results. The difference with our study is that Yu et al. ${ }^{27}$ excluded NPC while we had four cases of NPCs.

Another similar study by Goldenberg et al. examined 300 head and neck cancer samples excluding NPC for the presence of EBV using quantitative PCR. He observed that 3 of 300 (1\%) tumor samples were overtly positive for EBV DNA. A total of 5 of 300 (2\%) tumor samples showed low levels and 68 of 300 tumor samples (23\%) showed trace levels of EBV DNA. Thus, the total $25.33 \%$ of patients were positive for EBV, which is correlating our observations.

The present study confirmed that with increase in the T/N stage of the HNSCC and LEC, the EBVP increased. When ELISA was employed for detection of EBV, the EBVP increased from $20 \%$ to $50 \%$ with the increase in stage from $\mathrm{Tl} / \mathrm{T} 2$ to $\mathrm{T} 3 / \mathrm{T} 4$, respectively, with $p$ value of 0.043 (Fischer exact test), which is statistically significant. While in the $\mathrm{N}$ stage it was seen that EBVP increased from $27.77 \%$ to $50 \%$ in N0 and N1/N2 stages, respectively, with $p$ value of 0.198 (Fischer exact test), which is statistically insignificant. Insignificant findings were also seen with EBV PCR and the stage of tumor. For T1/ T2, the EBVP is $25 \%$ and increases to $35 \%$ and $50 \%$ with increase in the stage from T3 to T4, respectively, with $p$ value of 0.504 (Fischer exact test). For N0/N1, EBVP is $27 \%$ and increases to $38.46 \%$ in N2 with $p$ value of 0.734 (Fischer exact test).

Kamel et al. ${ }^{30}$ in his study of EBV in HNSCC found no significant increase in EBV antibody titer with stage of tumor, which is 
consistent with abovementioned results. Yu et al. ${ }^{27}$ states in his study that EBV DNA concentrations in patients with SCC of different stages and T stages did not vary significantly with these parameters, thus simulates our observations.

The current study confirmed that ELISA is more sensitive but less specific than PCR in detecting plasma EBV with sensitivity and specificity of $100 \%$ and $84.5 \%$, respectively. These observations are in accordance of with the study of Kamel et al. ${ }^{30}$ who in his study compared immunohistochemical staining and plasma ELISA for EBV detection in head and neck carcinomas and found that 19 (38\%) patients were immunoreactive using the immunohistochemical staining method and 41 (82\%) were positive using ELISA. Anti-EBV staining in the control sections revealed negative results. Whereas four (93.3\%) of controls were positive with ELISA. They concluded that ELISA gave more false positive results.

\section{Conclusion}

- Epstein-Barr virus is a potential carcinogenic virus which, has definite association with head and neck malignancies even in endemic areas.

- Most of the head and neck malignancies are present in advanced stages, so there is a need to screen the population early to prevent dreadful morbidity and mortality associated with disease.

- Noninvasive simple plasma-based detection of EBV may serve as a potential screening test.

- Antibodies against the certain antigens of the EBV can be detected in large percentage of general population. The detection of these antibodies indicates antigenic stimulation with the virus, although their presence in suspected cases cannot be used definitively for the diagnosis of occult head and neck carcinomas.

- Recent data indicate the role of EBV in the epigenetic alterations in several types of cancers including gastric carcinoma, NPC, and lymphomas.

- A consistent association between EBV and LECA of the salivary gland was found.

- The presence of EBV in these tumors represents a potential "tumor-specific" targeting opportunity for the development of new therapeutics.

\section{Ethical Approval}

Ethical clearance was given by ethical committee of the institution.

\section{InFORMED CONSENT}

Informed consent was obtained from all individual participants included in the study.

\section{REFERENCES}

1. Goldenberg D, Golz A, Netzer A, et al. Epstein-Barr virus and cancers of the head and neck. Am J Otolaryngol 2001;22(3):197-205. DOI: 10.1053/ajot.2001.23429.

2. Yang $\mathrm{HJ}$, Cho YJ, Kim HS, et al. Association of $\mathrm{p} 53$ and $\mathrm{BCL}-2$ expression with Epstein-Barr Virus infection in the cancers of head and neck. Head Neck 2001;23(8):629-636. DOI: 10.1002/hed.1089.

3. Lin JC, Chen KY, Wang WY, et al. Detection of Epstein-Barr virus DNA in the peripheral-blood cells of patients with nasopharyngeal carcinoma: relationship to distant metastasis and survival. J Clin Oncol 2001;19(10):2607-2615. DOI: 10.1200/JCO.2001.19.10.2607.
4. Parkin DM, Bray F, Ferlay J, et al. Global cancer Statistics. CA Cancer J Clin 2005;55(2):74-108, 2002.

5. Blot WJ, Mclaughlin JK, Winn DM, et al. Smoking and Drinking in relation to oral and pharyngeal cancer. Cancer Res 1988;48(11): 3282-3287.

6. Zeka A, Gore R, Kriebel D. Effects of alcohol and tobacco on aerodigestive cancer risks: a meta-regression analysis. Cancer Causes Control 2003;14(9):897-906. DOI: 10.1023/B:CACO.0000003854.34221. a8.

7. Nair S, Pillai MR. Human papillomavirus and disease mechanisms: relevance to oral and cervical cancers. Oral Dis 2005;11(6):350-359. DOI: 10.1111/j.1601-0825.2005.01127.x.

8. Lyons SF, Liebowitz DN. The roles of human viruses in the pathogenesis of lymphoma. Semin Oncol 1998;25(4):461-475.

9. Lei KIK, Chan LYS, Chan WY, et al. Quantitative analysis of circulating cell-free Epstein-Barr virus (EBV) DNA levels in patients with EBVassociated lymphoid malignancies. Br J Haematol 2000;111(1):239246. DOI: 10.1046/j.1365-2141.2000.02344.x.

10. Shinokuma A, Hirakawa N, Tamiya S, et al. Evaluation of Epstein-Barr virus infection in sinonasal small round cell tumors. J Cancer Res Clin Oncol 2000;126(1):12-18. DOI: 10.1007/PL00008459.

11. Cruz I, Van den Brule, Brink AJ, AA, et al. No direct role for EpsteinBarr virus in oral carcinogenesis: a study at the DNA, RNA and Protein levels. Int J Cancer 2000;86(3):356-361. DOI: 10.1002/(sici)10970215(20000501)86:3<356::aid-ijc9>3.0.co;2-w.

12. Cruz I, Van den Brule, Steenbergen AJ, RD, et al. Prevalence of EpsteinBarr virus in oral squamous cell carcinomas, premalignant lesions and normal mucosa-a study using the polymerase chain reaction. Oral Oncol 1997;33(3):182-188. DOI: 10.1016/S0964-1955(96)00054-1.

13. Kobayashi I, Shima K, Saito I, et al. Prevalence of Epstein-Barr virus in oral squamous cell carcinoma. J Pathol 1999;189(1):34-39. DOI: 10.1002/(SICI)1096-9896(199909)189:1<34::AID-PATH391>3.0.CO;2-4.

14. Maeda T, Hiranuma $H$, Matsumura S, et al. Epstein-Barr virus infection and response to radiotherapy in squamous cell carcinoma of the oral cavity. Cancer Lett 1998;125(1-2):25-30. DOI: 10.1016/S03043835(97)00485-0.

15. Gonzalez-Moles M, Gutierrez J, Ruiz I, et al. Epstein-Barr virus and oral squamous cell Carcinoma in patients without HIV infection: viral detection by polymerase Chain reaction. Microbios 1998;96(383): 23-31.

16. Lin $H$, Rao H, Saku U. The significance of detecting EB. Virus and its products in benign and malignant lymphoepithelial lesions of the salivary glands (Chinese). Chung-Hua Ping Li Hsueh Tsa Chih Chinese J Pathol 1997;26:225-228.

17. Leung SY, Chung LP, Yuen ST, et al. Lymphoepithelial carcinoma of the salivary gland: in Situ detection of Epstein-Barr virus.J Jlin Pathol 1995;48(11):1022-1027. DOI: 10.1136/jcp.48.11.1022.

18. Shimakage M, Sasagawa T, Yoshino K, et al. Expression of EpsteinBarr virus in nasopharyngeal and hypopharyngeal carcinomas. Hum Pathol 1999;30(9):1071-1076.

19. Frank DK, Cheron F, Cho $\mathrm{H}$, et al. Nonnasopharyngeal lymphoepitheliomas (undifferentiated carcinomas) of the upper aerodigestive tract. Ann Otol Rhinol Laryngol 1995;104(4 Pt 1):305310. DOI: $10.1177 / 000348949510400410$.

20. Kim KI, Kim YS, Kim HK, et al. The detection of Epstein-Barr virus in the lesions of salivary Glands. Pathol Res Pract 1999;195(6):407-412. DOI: $10.1016 /$ S0344-0338(99)80014-4.

21. Luna MA. Salivary glands. In: Pilch BZ. ed. Head and Neck Surgical Pathology. Philadelphia: Lippincott Williams and Wilkins; 2001. pp. 284-349.

22. Fahraeus R, Fu HL, Ernberg I, et al. Expression of Epstein-Barr virus-encoded proteins in nasopharyngeal carcinoma. Int J Cancer 1988;42(3):329-338. DOI: 10.1002/ijc.2910420305.

23. Young LS, Dawson CW, Clark D, et al. Epstein-Barr virus Gene expression in nasopharyngeal carcinoma. J Gen Virol 1988;69(5): 1051-1065. DOI: 10.1099/0022-1317-69-5-1051.

24. Chapman A, Rickinson A. Epstein-Barr virus in Hodgkin's disease. Ann Oncol 1998;9(Suppl 5):S5-S16. DOI: 10.1093/annonc/9.suppl_5.S5. 
25. Jones J, Shurin S, Abramowsky C, et al. T-Cell lymphomas containing Epstein-Barr viral DNA in patients with chronic Epstein-Barr virus infections. N Engl J Med 1988;318:733-741. DOI: 10.1056/ NEJM198803243181203.

26. Weiss L, Jaffe E, Liu X, et al. Detection and localization of EpsteinBarr viral genomes in angioimmunoblastic lymphadenopathy-like lymphomas. Blood 1992;79(7):1789-1795.

27. Yu KH, Dennis Lo YM, Tse GM, et al. Quantitative Analysis of Cell-Free Epstein-Barr Virus DNA in Plasma of Patients with Nonnasopharyngeal Head and Neck carcinoma. Clin Cancer Res 2004;10(5):1726-1732. DOI: 10.1158/1078-0432.CCR-0991-3.

28. Atlana GA. American Cancer Society. Retrieved December 26, 2012.

29. Abdulamir AS, Hafidh RR, Abdulmuhaimen N, et al. The distinctive profile of risk factors of nasopharyngeal carcinoma In comparison with other head and neck cancer types. BMC Public Health 2008;8:400. DOI: 10.1186/1471-2458-8-400.

30. Kamel AH, el-Barawy, Hashish MH. Epstein-Barr virus in head and neck squamous cell carcinoma. East Mediterr Health J 2003;9(3): 364-371.

31. National Cancer Institute. Head and Neck Cancers. Reviewed February 1, 2013.

32. Wyss A, Hashibe M, Chuang S-C, et al. Cigarette, Cigar, and Pipe Smoking and the Risk of Head and Neck Cancers: Pooled Analysis in the International Head and Neck Cancer Epidemiology Consortium. Am J Epidemiol 2013;178(5):679-690. DOI: 10.1093/aje/kwt029.

33. Majid M, Rafat Panah H, Zamanian A. Epstein - Barr virus antibody titers in non nasopharyngeal head and neck squamous cell carcinoma. Iran J Otorhinolaryngol 2006;18(45):61-65.

34. Muderris T, Rota S, Muderris T. Erdogan Inal, Isıl Fidan. Does EpsteinBarr virus infection have an influence on the development of laryngeal carcinoma? Detection of EBV by Real-Time Polymerase Chain Reaction in tumour tissues of patients with laryngeal carcinoma. Braz J Otorhinolaryngol 2013;79(4):418-423. DOI 10.5935/1808-8694.20130075.

35. Mao EJ, Smith CJ. Detection of Epstein-Barr virus (EBV) DNA by the polymerase chain reaction (PCR) in oral smears from healthy individuals and patients with oral squamous cell carcinoma. J Oral Pathol Med 1993;22(1):12-17. DOI: 10.1111/j.1600-0714.1993.tb00112.x.

36. Horiuchi K, Mishima K, Ichijima K, et al. Epstein-Barr virus in the proliferative diseases of squamous epithelium in the oral cavity. Oral Surg Oral Med Oral Pathol Oral Radiol Endod 1995;79(1):57-63. DOI: 10.1016/S1079-2104(05)80075-7.

37. Sand LP, Jalouli, Larsson PA, et al. Prevalence of Epstein Barr Virus in oral squamous cell carcinoma, oral lichen planus and normal oral mucosa. Oral Surg, Oral Med, Oral Pathol, Oral Radiol, Endod 2002; 93(5):586-592. DOI: 10.1067/moe.2002.124462.

38. D, Tiwawech, S, Chindavijak, P, Saelee, et al. Detection of IgA Antibody Against Epstein-Barr Virus Nuclear Antigen 1 in Nasopharyngeal Carcinoma Patients by ELISA. Thai Cancer J 2008;28(2):83-92.

39. Twu C-W, Wang W-Y, Liang W-M, et al. Comparison of the prognostic impact of serum anti-EBV antibody and plasma EBV DNA assays in nasopharyngeal carcinoma. Int J Radiation Oncology Biol, Phys 2007;67(1):130-137. DOI: 10.1016/j.ijrobp.2006.07.012.

40. Trimeche M, Ziadi S, De Leval L, et al. Prevalence of Epstein-Barr Virus in non-Hodgkin's lymphomas in central region of Morshed K, Dacewiez PS, Zymanski M, Rajtar B, Ziaja SM. Epstein-Barr Virus antibodies in patients With Laryngeal and hypopharyngeal cancer. Ann Univ Mariae Curie Sklodowska 2003;58(2):227-231.

41. Morshed K, Polz-Dacewicz M, Szymański M, et al. Epstein-Barr virus antibodies in patients with laryngeal and hypopharyngeal cancer. Ann Univ Mariae Curie Sklodowska Med 2003;58(2):227-231.

42. Kim A-Y, Jong-Lyel, Kim JM. Association of Epstein Barr Virus in Head and Neck cancer in an endemic area. Korean J Otolaryngol Head Neck Surg 2007;50(3):235-239. 